\title{
The effects of rainfall on the stability of soil slopes in Khanh Vinh district, Khanh Hoa province
}

- Nguyen Thanh Danh ${ }^{1}$

- Dau Van Ngo ${ }^{2}$

- Ta Quoc Dung ${ }^{2}$

${ }^{1}$ Mien Trung University of Cilvil Engineering, MUCE

${ }^{2}$ Ho Chi Minh city University of Technology, VNU-HCMC

(Manuscript Received on August 10 $0^{\text {th }}$,2015; Manuscript Revised on October 15 ${ }^{\text {th }}, 2015$ )

\begin{abstract}
This study presents a procedure for calculating the change of the safety factor for unsaturated slopes of homogenous, residual soils suffering from rainfall infiltration within Khanh Vinh district, Khanh Hòa province. Rainfall is supposed as a main trigger caused failure of the potential sliding slopes. Rainwater into the slope due to infiltration caused an increase in moisture content and negative pore water pressure; a decrease in matric suction and in shear strength on the failure surface. Thus, slopes are reduced stability and can be failed. Soil permeability and rainfall intensity the instability of slopes due to rainfall, while the initial water table location and slope geometry only played a secondary role. A numerical model of analysis coupled seepage-stability used to simulate the seepage and slope stability under conditions of specific environment such as soil permeability, rainfall intensity, water table location and slope geometry in the study area. The relationships between safety factor and rainfall intensity, soil permeability, angle slope, high slope were identified to provide a good indication for the management of landslide hazards under the effects of rainfall.
\end{abstract} were found to be the primary factors controlling

Keywords: slope stability, unsaturated residual soil, matric suction, rainfall intensity.

\section{INTRODUCTION}

The impact of climate change affecting rainfall patterns (intensity and duration of rain) in many parts of the world causing many landslides. Many high terrains with tropical and subtropical climate covered mainly by residual soils are prone to frequent rainfall-induced slope failures. This issue is often result in costly repair

works and pose considerable concern to infrastructure developments and the environmental protection.

This problem occurs more by the strong socioeconomic development and rising to huge demand for construction of technical infrastructure. South central region in general 
and Khanh Vinh district, Khanh Hoa province in particular (Fig. 1, 2), prolonged rainy season with heavy rainfall is the main cause to trigger landslides and increase the level of destructive landslides.

Slope failures due to rainwater infiltration has long been a topic of interest in geotechnical and geo-environmental engineering. Numerous researchers have investigated the causes of slope failures in tropical regions and concluded that rainwater infiltration is the most important factor triggering the instability of slopes. The rainwater infiltration causing changes in porewater pressures and soil permeability are two factors that significantly influenced in the instability of slopes.

Despite the importance of rainfall intensity and soil permeability to the instability of slopes has been widely acknowledged, the slope geometry, initial water table location, antecedent rainfall and rainfall pattern also contribute to accelerate the process of slope failures. However, this study mainly analyzed to assess the role of the rainfall to change safety factor of the slopes under different conditions such as rainfall intensity, soil permeability and slope geometry.

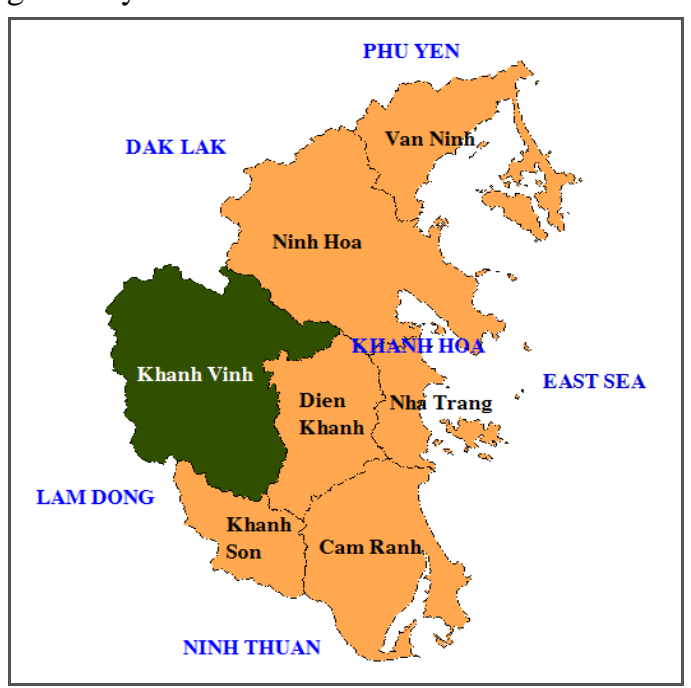

Figure. 1. Study area: Khanh Vinh district

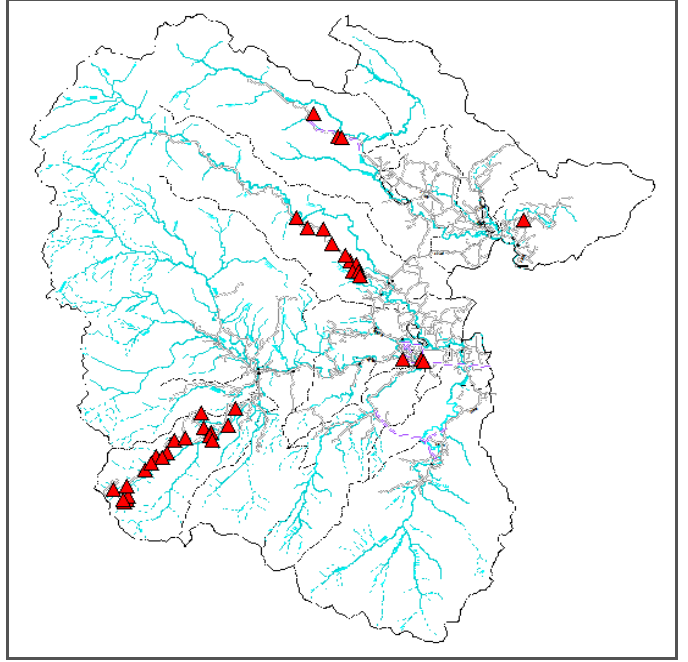

Figure. 2. Study sites in Khanh Vinh district

\section{MECHANISM OF THE SLOPE FAILURE}

Many natural and artificial slopes remain stability for a long time but then destroyed during rainstorms. Mechanism that leads to slope failures is that the negative pore-water pressure stars to increase when water starts to infiltrate the unsaturated soil lying on groundwater table and groundwater table will rise during rain (Fig.3). The process of rainwater infiltration into the slope that appear wetting front (local saturation), disappear negative porewater pressure and decrease matric suction in unsaturated soil. Thus, the shear strength of soil reduced to a smaller mobilised shear strength along the potential slip surface.

The cases of rainwater infiltration into the slope reducing matric suction and rising initial groundwater table effecting the stability of the slope can be summarized by the diagrams in Fig. 4 [1]. 

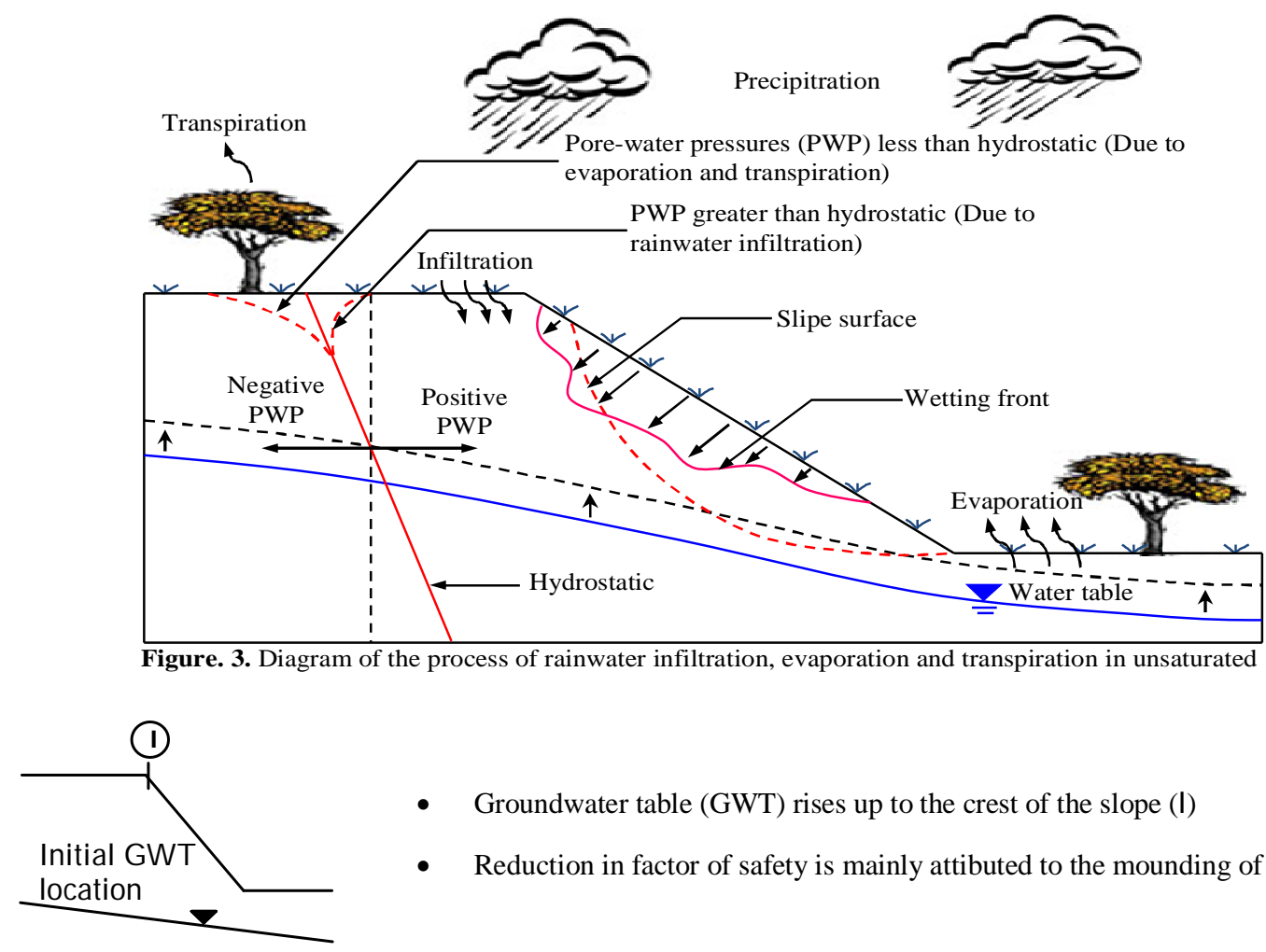

- Groundwater table (GWT) rises up to the crest of the slope (I)

- Reduction in factor of safety is mainly attibuted to the mounding of GWT

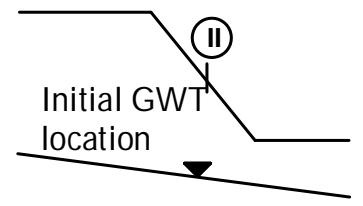

- $\quad$ GWT rises up to the mid-slope (II)

- Reduction in factor of safety in parttly attributed to the mounting of GWT and is partly attributed to the reduction in matric suction due to infiltration in the unsaturated zone above the GWT

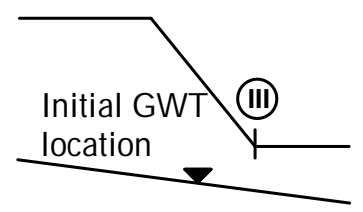

- $\quad$ GWT rises up to the toe of the slope (III)

- Reduction in factor of safety is mainly attributed to the reduction in matric suction due to infiltration in the unsaturated zone above the GWT and is marginally attributed to the mounting of GWT

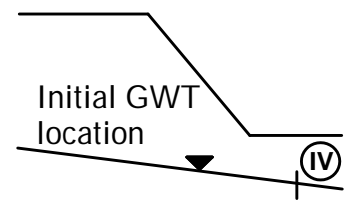

- $\quad$ No mounding or relatively small mounding of GWT (IV)

- Reduction in factor of safety is mainly attributed to the reduction in matric suction due to infiltration in the unsaturated zone above the GWT

Figure. 4. Diagrams describe the influence of rainwater infiltration and rising groundwater table in the slope 
Table 1. Basic properties of the residual soil

\begin{tabular}{|c|c|c|c|c|c|}
\hline \multirow[b]{2}{*}{ Properties } & \multirow[b]{2}{*}{ Symbol } & \multirow[b]{2}{*}{ Unit } & \multicolumn{3}{|l|}{ Soil } \\
\hline & & & Clay & Sandy clay & $\begin{array}{l}\text { Sandy clay mixed } \\
\text { with gravel }\end{array}$ \\
\hline Gravel & & $\%$ & 1 & 5 & 34 \\
\hline Sand & & $\%$ & 32 & 61 & 35 \\
\hline Silt & & $\%$ & 29 & 14 & 13 \\
\hline Clay & & $\%$ & 38 & 20 & 18 \\
\hline Liquid limit & $L L$ & $\%$ & 46 & 34 & 36.3 \\
\hline Plastic limit & $L P$ & $\%$ & 28 & 22 & 23.9 \\
\hline Plasticity index & $P I$ & $\%$ & 18 & 12 & 12.4 \\
\hline Moisture content & $W$ & $\%$ & 29 & 20.68 & 23.53 \\
\hline Unit weight wet & $\gamma$ & $\mathrm{kN} / \mathrm{m}^{3}$ & 17.4 & 17.3 & 18.0 \\
\hline Unit weight of saturation & $\gamma_{s}$ & $\mathrm{kN} / \mathrm{m}^{3}$ & 18.5 & 18.9 & 19.3 \\
\hline Unit weight dry & $\gamma_{d}$ & $\mathrm{kN} / \mathrm{m}^{3}$ & 13.5 & 14.2 & 14.6 \\
\hline Specific gravity & $G_{s}$ & - & 2.68 & 2.69 & 2.73 \\
\hline Porosity & $n$ & $\%$ & 0.496 & 0.472 & 0.465 \\
\hline Void ratio & $e_{o}$ & - & 0.985 & 0.894 & 0.870 \\
\hline Saturation & $S_{r}$ & $\%$ & 79 & 62 & 74 \\
\hline Angle of friction & $\phi^{\prime}$ & o & 16 & 17 & 18 \\
\hline Cohesion & $c^{\prime}$ & $\mathrm{kN} / \mathrm{m}^{2}$ & 21 & 15 & 18 \\
\hline Compressive index & $a_{100-200}$ & $\mathrm{~m}^{2} / \mathrm{MN}$ & 0.044 & 0.040 & 0.050 \\
\hline $\begin{array}{l}\text { Saturated coefficient of } \\
\text { permeability }\end{array}$ & $k_{s}$ & $\mathrm{~m} / \mathrm{s}$ & $2.09 \times 10^{-7}$ & $1.55 \times 10^{-6}$ & $2.03 \times 10^{-5}$ \\
\hline
\end{tabular}

\section{METHODOLOGY}

Based on the documents have been surveyed and gathered from field then theoretical studies of permeability and stability were applied in unsaturated soil slope. In this study, using numerical model to analyze infiltration in unsaturated soil slope. The results from analyzing permeability were used to calculate slope stability by Morgenster-Price's limit equilibrium method.

\subsection{Designing parametric study}

Rainfall intensity and the soil permeability were considered the primary parameters affecting to the process of the rainwater infiltration into the slope, increase in pore-water pressure in during rain and decrease in slope 
stability, while the other parameters such as initial groundwater table location, slope angle and slope height contributing to determine the initial factor of safety of the slope only played a secondary role.

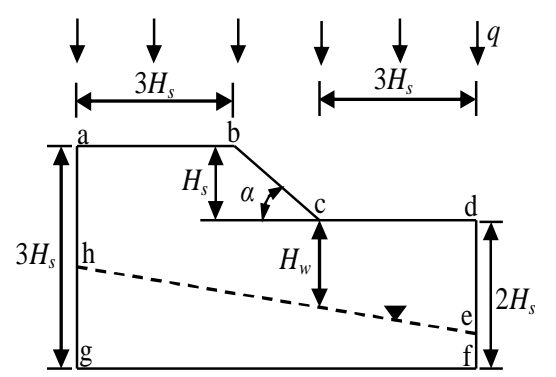

Figure. 5. Slope geometry and boundary conditions for homogeneous soil slope used in parametric study

In analyzing slope stability, the factor of safety is dependent variable, the other parameters such as rainfall intensity $(q=I)$, saturated coefficient of permeability $\left(k_{s}\right)$, initial water table location $\left(H_{w}\right)$, slope angle $(\alpha)$ and slope height $\left(H_{s}\right)$ is independent variable. The parameters of slope stability analysis were performed on homogeneous soil slope in Fig. 5.

The residual soil slopes composed mainly from three typical types of weathered soil of lithological complexes aluvi-proluvi-deluvi (apdQ) [2] as clay, sandy clay and sandy clay mixed with gravel having soil properties shown in Table 1.

The study area, heavy rainfall usually occurs between the September and November annually. In this research, uniform rainfall pattern with constant rainfall intensity and the average precipitation of the months in 20102011 is used in the calculation, the number of continuous rainy day is 10 days [3, 4]. Rainfall intensity value is selected based on the average rainfall intensity and highest rainfall intensity of day [2-4]. Due to high terrain and strong cleavage, the weathered soils do not contain water and groundwater table was supposed no existing.

Slope height and slope angle are chosen from statistical calculations in the following [2]: five slope angles change from 15 to $75^{\circ}(15,30$, 45, 60 and $75^{\circ}$ ); five slope height change from 5 to $40 \mathrm{~m}(5,10,20,30$ and $40 \mathrm{~m})$. The number of combinations and the series of parametric study for slope stability analysis were showed in Table 2.

In order to simplify in the survey impacting of rain for the slope stability slope mainly due to changes in pore-water pressure in the slope, the following analysis with hypothesis that slopes are formed by sandy clay and are considered to have average physical mechanical properties of above three types of soil.

Series A parametric studies were intended to evaluate the effect of soil permeability (coefficient of permeability) with respect to change the factor of safety of the slope.

Series B parametric studies were intended to evaluate the effect of the rainfall intensities with respect to change the factor of safety of the slope.

Series C studies were intended to evaluate the effect of the rainfall intensities and the slope angles with respect to change the factor of safety of the slope.

Series D studies were intended to evaluate the effect of the rainfall intensities and the slope heights with respect to change the factor of safety of the slope.

\subsection{Soil-water characteristic curve (SWCC)}

Based on the measured grain-size distribution, the equation (1) performing the SWCCs (Fig. 6) for the soil types in the study area was determined using the modified Kovacs estimation method (Kovacs 1981; Aubertin et al,. 2003) $[5,6]$. 


$$
S_{r}=\frac{\theta_{w}}{n}=S_{c}+S_{a}^{*}\left(1-S_{c}\right)
$$

Where, $S_{r}$ : the degree of saturation; $\theta_{w}$ : the volumetric water content; $n$ : the initial porosity of the soil; $S_{c}$ : the saturation associated with the capillary component and $S_{a}^{*}$ : the saturated associated with the adhesive component.

Table 2. The number of combinations and the series of parametric study for slope stability analysis

\begin{tabular}{|c|c|c|c|c|c|c|}
\hline $\begin{array}{l}\text { Study } \\
\text { series }\end{array}$ & $\begin{array}{l}\text { Saturated coefficient } \\
\text { of permeability, } \\
k_{s}(\mathbf{m} / \mathbf{s})\end{array}$ & $\begin{array}{l}\text { Rainfall } \\
\text { intensity, } \\
I(\mathrm{~mm} / \mathrm{h})\end{array}$ & $\begin{array}{c}\text { Slope } \\
\text { angle, } \\
\alpha\left({ }^{\circ}\right)\end{array}$ & $\begin{array}{c}\text { Slope } \\
\text { height, } \\
H_{s}(\mathbf{m})\end{array}$ & $\begin{array}{c}\text { Duration } \\
\text { of rain, } \\
t(h)\end{array}$ & $\begin{array}{l}\text { Number of } \\
\text { combination }\end{array}$ \\
\hline A & $\begin{array}{l}k_{s 1}=2.09 \times 10^{-7} \\
k_{s 2}=1.55 \times 10^{-6} \\
k_{s 3}=2.03 \times 10^{-5}\end{array}$ & $\begin{array}{c}0.5 \\
1 \\
2 \\
5 \\
10 \\
20\end{array}$ & 45 & 10 & 240 & 18 \\
\hline B & $k_{s 2}=1.55 \times 10^{-6}$ & $\begin{array}{c}0.5 \\
1 \\
2 \\
5 \\
10 \\
20\end{array}$ & 45 & 10 & 240 & 6 \\
\hline $\mathrm{C}$ & $k_{s 2}=1.55 \times 10^{-6}$ & $\begin{array}{c}0.5 \\
1 \\
2 \\
5 \\
10 \\
20\end{array}$ & $\begin{array}{l}15 \\
30 \\
45 \\
60 \\
75\end{array}$ & 10 & 240 & 30 \\
\hline $\mathrm{D}$ & $k_{s 2}=1.55 \times 10^{-6}$ & $\begin{array}{c}1 \\
5 \\
10\end{array}$ & 45 & $\begin{array}{c}5 \\
10 \\
20 \\
30 \\
40\end{array}$ & 240 & 15 \\
\hline
\end{tabular}




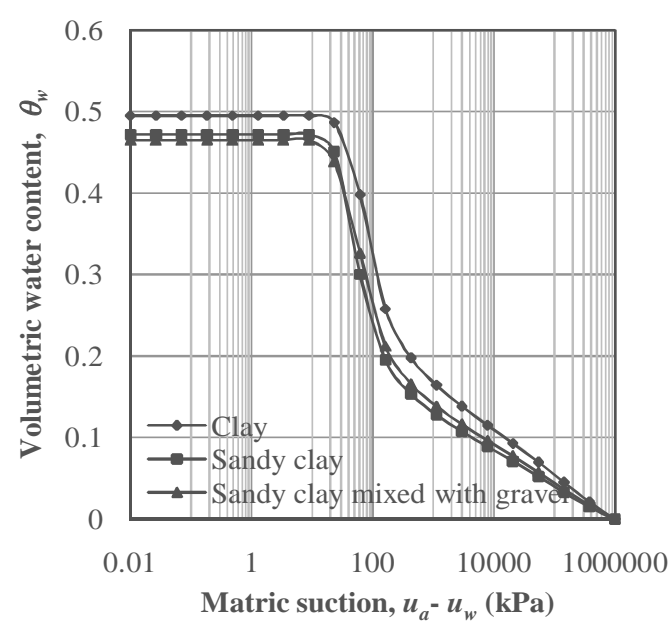

Figure. 6. Soil-water characteristic curve

\subsection{Permeability function}

The permeability function (2) suggested by Leong và Rahardjo (1997b) was used in this study because it is simple, easy to use and represents the most general relationship between permeability function and SWCC [5], the curves of permeability function of three soil types (clay, sandy clay and sandy clay mixed with gravel) were shown in Fig. 7.

$$
k_{w}=k_{s} \Theta^{p}
$$

Where, $k_{w}$ : the coefficient of permeability with respect to water as a function of matric suction (the unsaturated coefficient of permeability); $k_{s}$ : the saturated coefficient of permeability; $p$ : the fitting parameter $(p=0.39)$ corresponded to the slope of the permeability function and $\Theta=\theta_{n} / \theta_{s}$ : the normalized volumetric water content; $\theta_{s}$ : the saturated volumetric water content $\left(\theta_{s}=n\right)$.

\subsection{Seepage analysis}

Seepage analysis to determine change in pore-water pressure in unsaturated-saturated soil slope due to rain. The governing partial differential equation (3) for a two-dimensional transient water flow in the homogeneous and

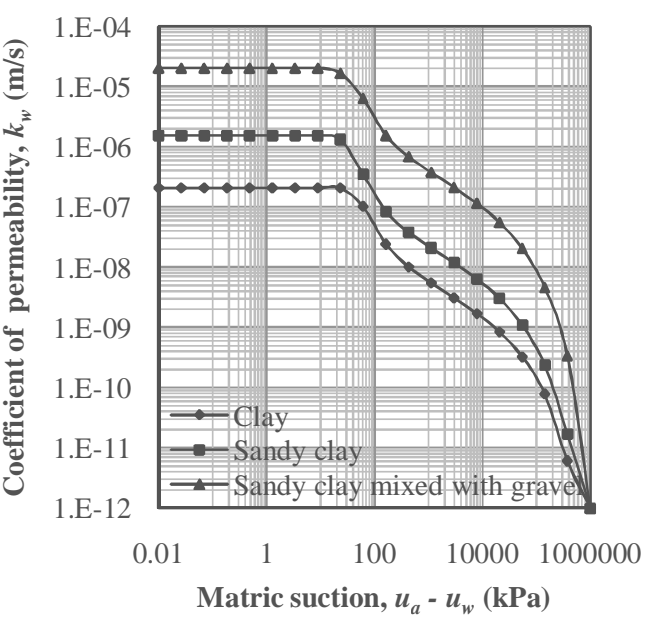

Figure. 7. Permeability function of the soil

isotropic soil slope used to analyze change in pore-water pressure.

$\frac{\partial}{\partial x}\left(k_{w x} \frac{\partial h_{w}}{\partial x}\right)+\frac{\partial}{\partial y}\left(k_{w y} \frac{\partial h_{w}}{\partial y}\right)+q=m_{w}^{2} \gamma_{w} \frac{\partial h_{w}}{\partial t}(3)$

Where, $h_{w}$ : hydraulic head or total head; $\gamma_{w}$ : unit weight of water; $k_{w x}, k_{w y}$ : coefficient of permeability with respect to water as a function of matric suction in the $\mathrm{x}, \mathrm{y}$ direction; $\partial h_{w} \partial \partial x$, $\partial h_{w} / \partial y$ : hydraulic head gradient in the $\mathrm{x}, \mathrm{y}$ direction; $q$ : applied boundary flux; $m_{w}^{2}$ : slope of the soil-water characteristic curve; $t$ : elapsed time.

The result of change in pore-water pressure is then used in slope stability analysis to assess change the factor of safety of the slope under the influence of rain. Finite element method is used to simulate unsteady-state water flow in the slope by SEEP/W module in the GeoStudio 2007 software [6].

\subsection{Slope stability analysis}

The shear strength equation of Fredlund và Rahardjo (1978) utilized in the slope stability analysis was the unsaturated shear strength equation to incorporate the contribution from the negative pore-water pressure. The equation for unsaturated shear strength is as follow (4): 


$$
\tau_{f f}=c+\left(\sigma_{f}-u_{a}\right)_{f} \operatorname{tg} \phi+\left(u_{a}-u_{w}\right)_{f} \operatorname{tg} \phi^{b}
$$

Where, $\tau_{f f}$ : shear strength of unsaturated soil; $c^{\prime}$ : effective cohesion; $\left(\sigma_{f}-u_{a}\right)$ : net normal stress; $\sigma_{f}$ : total normal stress; $u_{a}$ : pore-air pressure; $\phi^{\prime}$ : effective angle of internal friction; $\left(u_{a}-u_{w}\right) f$ : matric suction; $u_{w}:$ pore-water pressure; $\phi^{b}$ : angle indicating the rate of increase in shear strength relative to the matric suction.

The shear strength of unsaturated soil was calculated with the value of $\phi^{b}$ which obtain from SWCC. The factor of safety of slope decreases as the pore-water pressure increases during rain. The change in pore-water pressure throughout the time rain derived from seepage analysis was integrated in SLOPE/W module (GeoStudio 2007) to analyze slope stability [7] according to Morgenstern-Price method.

Theoretically, slope instability is considered as the smallest factor of safety is less than one. However, in fact so many different influences from objectiveand subjectiveconditions as the deviation of the data collected, the error in the experiments and measurements can be significant. In order to exclude above mistakes can choose the minimum factor of safety from 1.2 to 1.4. In this study, the smallest the factor of safety for slope stability chosen as 1.3.

\section{Results and discussion}

\subsection{Effect of coefficient of permeability}

Result in analysis study series A, suggesting saturated coefficient of permeability have an important role for the stability of the slope (Fig. 8). When the rainy period is more than 3 days, the factor of safety will change much if the slope formed by soil having small coefficient of permeability $\left(k_{s l}=2.09 \times 10^{-7} \mathrm{~m} / \mathrm{s}\right.$ $=0.75 \mathrm{~mm} / \mathrm{h} ; k_{s 2}=1.55 \times 10^{-6} \mathrm{~m} / \mathrm{s}=5.58 \mathrm{~mm} / \mathrm{h}$ ) and little change when the slope formed by soil having large coefficient of permeability $\left(k_{s 3}=\right.$ $2.03 \times 10^{-5} \mathrm{~m} / \mathrm{s}=73.08 \mathrm{~mm} / \mathrm{h}$ ). Comparison of between values of saturated coefficient of permeability $\left(k_{s}\right)$ and rainfall intensity $(I)$, the factor of safety of slope dropped sharply when the ratio $k_{s} / I$ changed from close one to three (mean values $k_{s}$ and $I$ see as close approximation) and slightly decrease when this ratio is quite large.

In the case of this study, the range of saturated coefficient of permeability that effect significantly on reducing of the factor of safety as $10^{-7} \mathrm{~m} / \mathrm{s} \leq k_{s} \leq 10^{-5} \mathrm{~m} / \mathrm{s}$ and the factor of safety is the smallest when saturated coefficient of permeability is $1.55 \times 10^{-6} \mathrm{~m} / \mathrm{s}$.

\subsection{Effect of rainfall intensity}

Results in analysis study series B, showing the factor of safety changes over time under different rainfall intensities (Fig. 9, 10). The factor of safety decreases more as the greater rainfall intensity. However, at the heavy rainfall intensities over $10 \mathrm{~mm} / \mathrm{h}$, the speed of reduction the factor of safety will decrease with time. This reason has proved to exist the threshold of rainfall intensity that at which the rainfall intensity increase, but the factor of safety hardly decrease. In this case, the threshold of rainfall intensity predicted greater than $20 \mathrm{~mm} / \mathrm{h}$.

Fig. 9, 10 show that the rainfall intensity of $10 \mathrm{~mm} / \mathrm{h}$, after a period of time more than seven days, the slope will be destabilized. Fig. 9 shows the rainfall intensity over $20 \mathrm{~mm} / \mathrm{h}$, after more than five days the slope will be destabilized. Thus, the factor of safety is related inversely to rainfall intensity and duration of rain. 

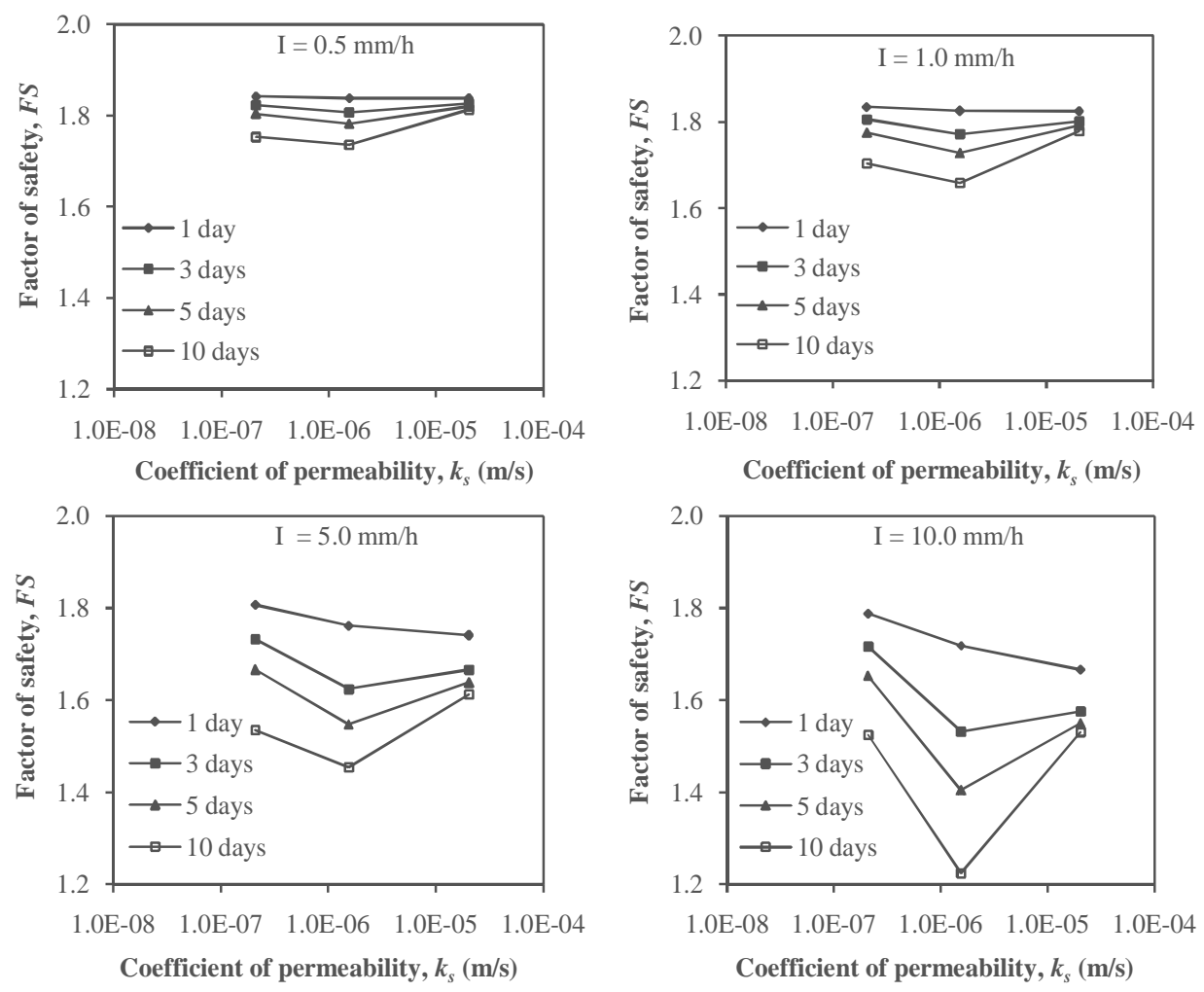

Figure. 8. Relationship between the factor of safety and the saturated coefficient of permeability

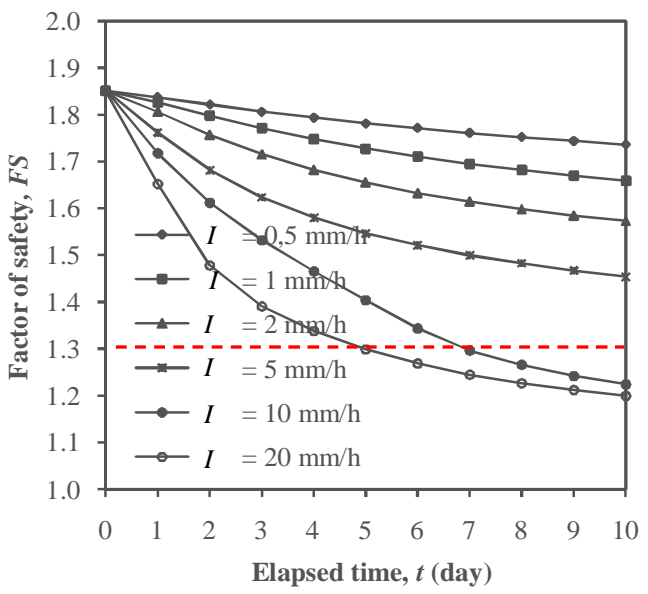

Figure. 9. Relationship between the factors of safety and time with different rainfall intensity

\subsection{Effect of slope geometry}

The effect of slope geometry is evaluated in terms of slope angle and slope height. The effect of slope angle on the stability of a

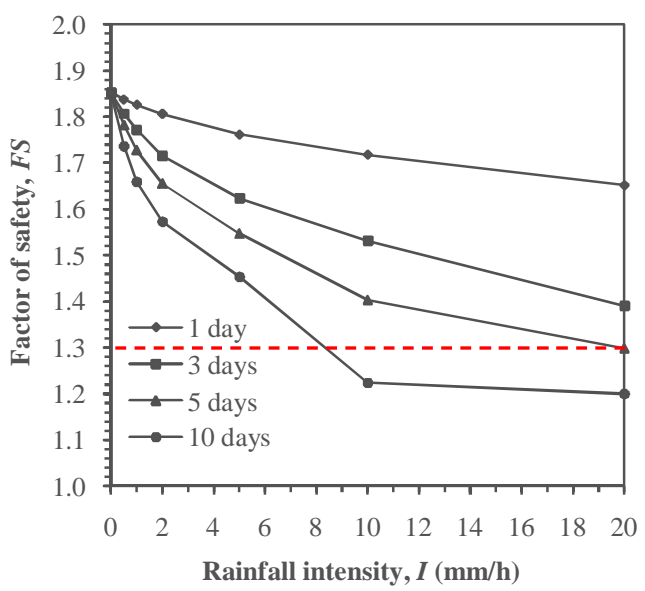

Figure. 10. Relationship between the factor of safety and the rainfall intensity

homogenous soil slope is describled first and is followed by the effects of slope height.

\section{Effect of slope angle}

According to result in analysis study series $\mathrm{C}$, there is inversely relative between the factor 
of safety and slope angle (Fig. 11). At the period of time rain and rainfall intensity, the greater the slope angle, the smaller the factor of safety. This is entirely consistent with reality, the slope having larger slope angle is lower the factor of safety comparing with the slope having smaller slope angle. In Fig. 11 also shows that, with the slope angle is less than $40^{\circ}$, the speed of reduction the factor of safety larger than the slope angle is greater than $40^{\circ}$. However, the slopes having small slope angles are difficult to destroy because the initial factor of safety is large. Thus, in the slopes having slope angles is small requiring a large rainfall intensity (I > 10 $\mathrm{mm} / \mathrm{h}$ ) to destroy the slopes. Most of the cases, the slope will be destroyed when the slopes having slope angles is smaller than $40^{\circ}$.

\section{Effect of slope height}

Results in analysis study series D (Fig. 12) under duration rainfall $1,3,5$ and 10 days showing the influence of the slope height to slope stability under different conditions of rainfall intensity. Rainfall intensity, duration rainfall and slope height considered as independent variables, while the factor of safety considered as dependent variable.

The factor of safety will be reduced when the slope height increases and the duration rainfall is long corresponding to different rainfall intensities. At each rainfall intensity, the longer the duration rainfall, the lower the factor of safety. The slopes with greater height, speed reduction of the factor of safety is low but slopes are generally easier to fail due to the low initial factor of safety, while the slopes with lower height, speed reduction of the factor of safety is fast but slopes are still stability due to the high initial factor of safety. For example, in the rainfall intensity $I=5$ and $10 \mathrm{~mm} / \mathrm{h}$, duration rainfal $t=3$ days, the the slopes higher than 18 and $20 \mathrm{~m}$ can be destroyed $(F S<1.3)$ but slopes with less than $18 \mathrm{~m}$ in height remained stable. All the cases examined above with respect to study series $\mathrm{D}$, in the slope without mounding the water table.

\section{CONCLUSIONS}

Soil-water characteristic curve (SWCC) can be determined directly from experiments in the laboratory, the field, as well as determined indirectly from the equations proposed by many authors. The experiments used to determine permeability function, shear strength with respect to different matric suction are often very difficult, expensive and time-consuming. However, permeability function and shear strength of the soil can be calculated indirectly from the soil-water characteristic curve. Thus, the soil-water characteristic curve is very important in unsaturated soil mechanics. Permeability function and shear strength equation allowing accurate analysis of the problem of infiltration by rain, slope stability over time when there is a change in water content, pore-water pressure in the environment of unsaturated-saturated soil.

The slopes composed mainly by residual soil due to weathering often in a state of unsaturated soil, does not exist groundwater table or the groundwater table is very deep. The dry season, transpiration and evaporation occur to increase the matric suction, increase shear strength and thus slope becomes more stable. Whereas, in the rainy season, rainwater infiltrate in slope and part of the land on the slope becomes saturated, thereby the negative porewater pressure increase, shear strength decrease dramatically and led to slope instability causing landslides. 

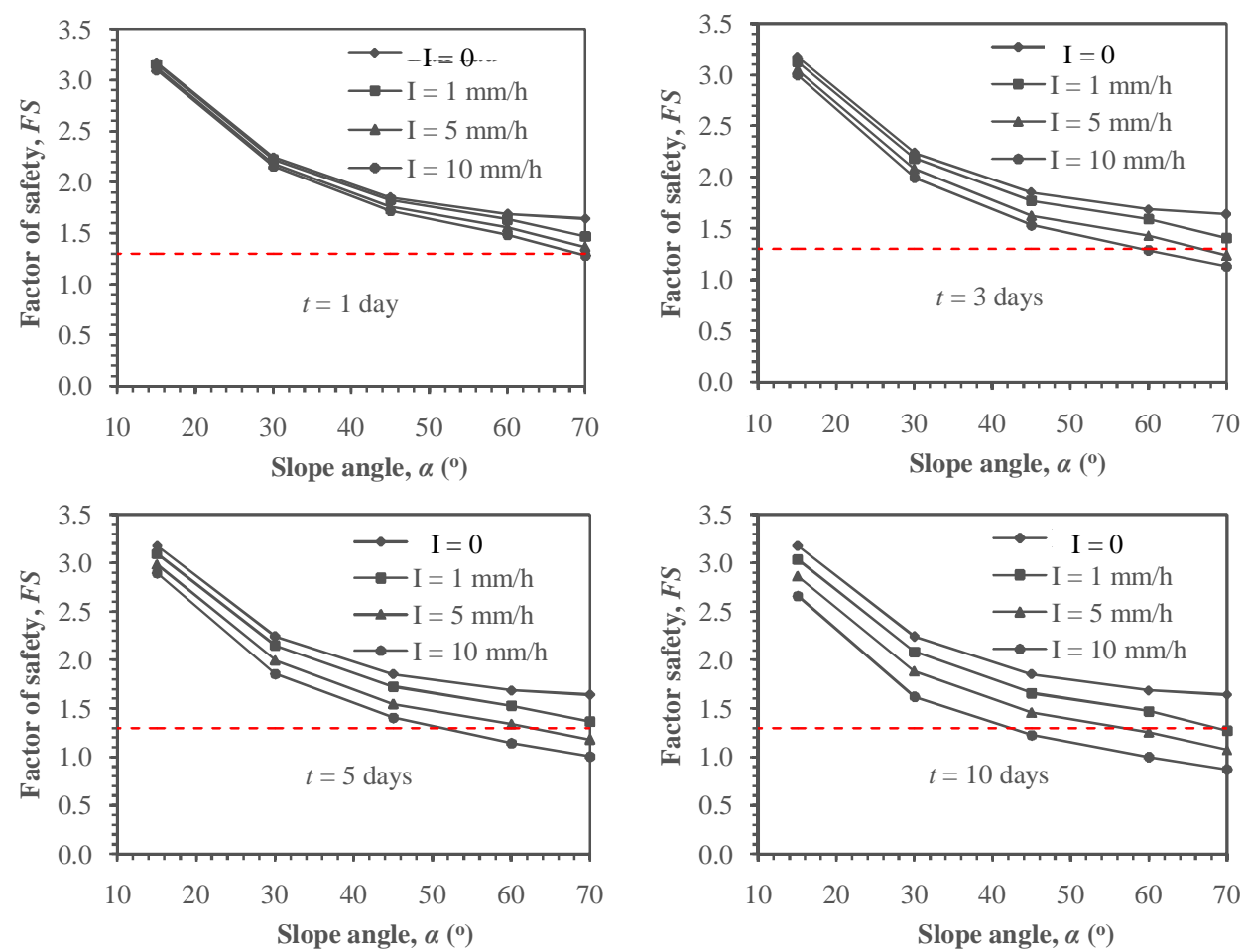

Figure. 11. Relationship between the factor of safety and the slope angle
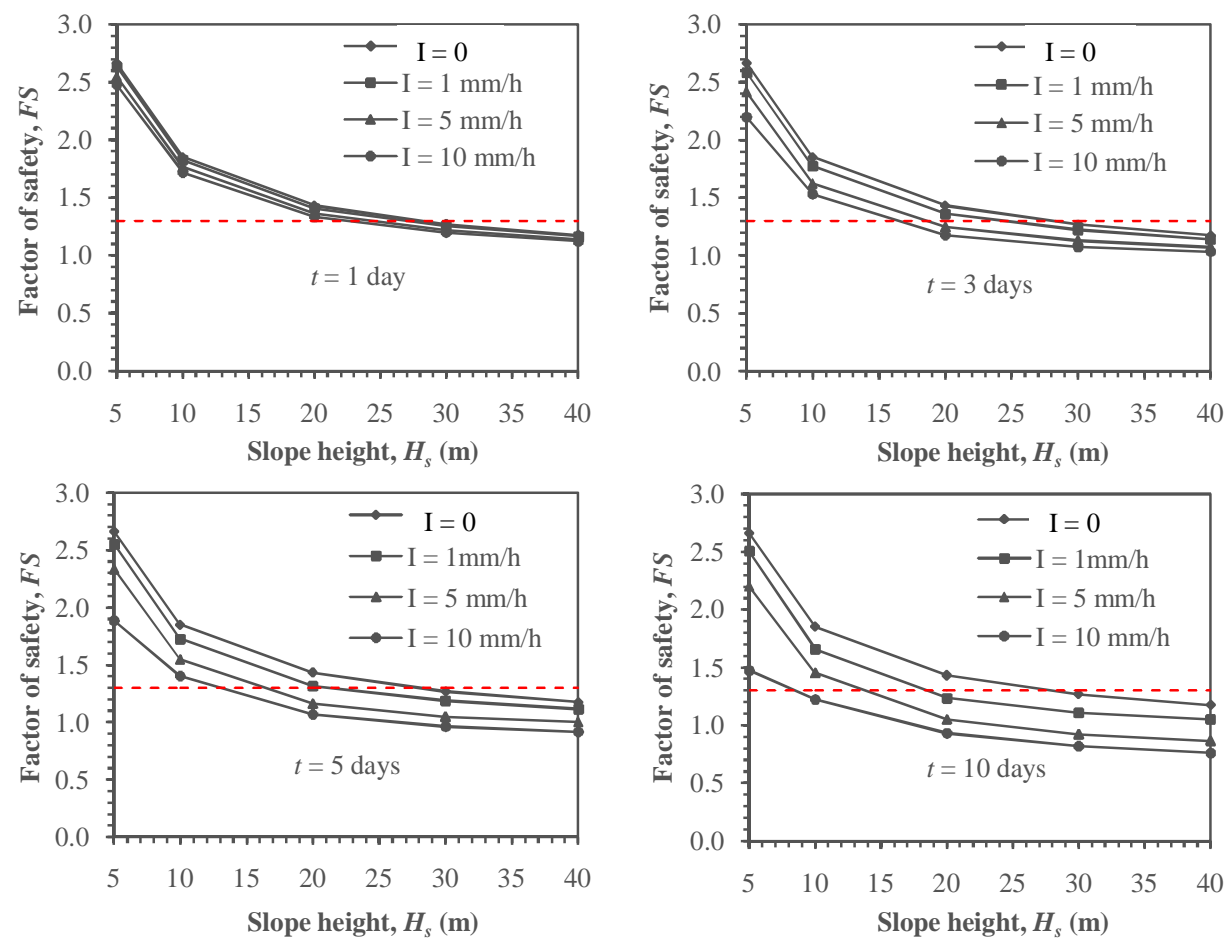

Figure. 12. Relationship between the factor of safety and the slope height 
The stability of slopes under rainy conditions dependent on the saturated coefficient of permeability, rainfall intensity, duration rainfall. The soil permeability of slope is very small $\left(k_{s}<k_{s l}=2.09 \times 10^{-7} \mathrm{~m} / \mathrm{s}\right)$ or very large $\left(k_{s}>k_{s 3}=2.03 \times 10^{-5} \mathrm{~m} / \mathrm{s}\right)$, the slope stability was affected virtually very little by the rain because large rainwater drain off surface or drain off rapidly downward, pore-water pressure do not increase significantly. The slopes having the saturated coefficient of permeability change from $k_{s 1}$ to $k_{s 3}$ and the ratio of the saturated coefficient of permeability with the rainfall intensity $\left(k_{\S} / I\right)$ less than one to three are likely to be affected by rain, pore-water pressure increases dramatically and the factor of safety reduce significantly.

The stability of the slope under rainy conditions often influenced by two factors as mounding of groundwater table and the wetting due to rainwater reducing the matric suction of the soil in the upper part of the slope. However, in this study, the most cases, the slopes reduced the stability due to decrease in matric suction.

Each type of soil composing slope having the different saturated coefficient of permeability always has a threshold value of the rainfall intensity corresponding, passing this threshold value, the factor of safety almost was not reduced. In the case of this study, the threshold value of rainfall intensity is greater than $20 \mathrm{~mm} / \mathrm{h}$.

The slope geometry has a certain influence on the stability of the slope because the slope height and slope angle only decide the initial factor of safety of the slope. The greater the slope height and the slope angle, the lower the initial factor of safety. Although, the slope of a large height and steep angle is easily destroyed due to rain because the initial factor of safety is low, in fact shows that the majority of cases, the slope was destroyed mainly due to the rainfall intensity and the saturated coefficient of permeability.

Most natural slopes are in a state of unsaturated soil and rainwater considered as the trigger factor causing landslides. Thus, the need to apply the theory of unsaturated soil mechanics to analyze, simulate and evaluate the stability of the unsaturated-saturated soil slope that results will be appropriate to reality comparing with the saturated soil mechanics.

The stability of the slopes vary in space and time under the influence of environmental factors such as the permeability of the soil, rainfall, evaporation, transpiration and vegetation. Thus, the analysis results from the numerical model should be adjusted and verified by measurement and observation in the field.

Acknowledgements: This research is funded by University of Technology, VNU-HCM in topic "Database for study of the effects of rainfall on the landslide in Khanh Vinh district, Khanh Hoa province", under grant number TNCS-DCDK-2015-22. The authors would like to thanks for allowing use of the material in this topic. 


\section{Ảnh hưởng của mưa đối với sự ổn định mái dốc trên địa bàn huyện Khánh Vĩnh, tỉnh Khánh Hòa}

- Nguyễn Thanh Danh ${ }^{1}$

- Đậu Văn Ngọ ${ }^{2}$

- Tạ Quốc Dũng ${ }^{2}$

${ }^{1}$ Trường Đại học Xây dựng Miền Trung, Bộ Xây dựng

${ }^{2}$ Trường Đại học Bách Khoa, ĐHQG-HCM

\section{TÓM TẮT}

Bài báo này tập trung tính toán sụ thay đổi hệ số ổn định các mái dốc đất tàn tích, đồng nhất không bão hòa chịu tác dụng bởi nước mura ngấm trên địa bàn huyện Khánh Vĩnh, tỉnh Khánh Hoà. Mura được xem nhu yếu tố kích hoạt làm phá hủy các mái dốc truợt tiềm năng. Nước mura ngấm vào mái dốc làm tăng độ ẩm và áp lực nước lỗ rông âm; giảm độ hút dính và súc chống cắt trên mặt phá hủy. Vì vậy, mái dốc giảm tính ổn định có thể dẫn đến phá hủy. Bên cạnh cuờng độ mua, tính thấm của đất là các yếu tố quan trọng thì các yếu tố về cấu tạo hình hoc mái dốc, mục nước ngầm ban đầu được xem là các yếu tố thứ yếu đối với sụ ổn định của mái dốc. Một mô hình số ghép đôi phân tích thấm-ổn định được sủ dụng để mô phỏng thấm và ổn định mái dốc duoói các điều kiện môi truờng đặc trung nhu tính thấm, cuòng độ mua và cấu tạo hình học mái dốc cho vùng nghiên cứu. Nhũng mối quan hệ giũa hệ số an toàn và cuờng độ mura, hệ số thấm, góc dốc, chiều cao mái dốc được rút ra nhằm hỗ trợ tốt cho việc quản lý tai biến trượ lở đất duoói ảnh huơng của mura.

Tù khóa: ổn định mái dốc, đất tàn tích không bão hòa, độ hút dính, cương độ mura.

\section{TÀI LIỆU THAM KHẢO}

[1]. H. Rahardjo, T. H. Ong, R. B. Rezaur, and E. C. Leong, "Factors Controlling Instability of Homogeneous Soil Slopes under Rainfall," Journal of Geotechnical and Geoenvironmental Engineering, vol. 133, pp. 1532-1543, 2007.

[2]. The Department of Science and Technology of Khanh Hoa, "Studying geological conditions, hydrology in moutainous Khanh Son and Khanh Vinh districts. Proposing solutions to construct works of sustainable transportation and irrigation," Khanh Hoa, 2011.

[3]. Ministry of Natural Resources and Environment - Institute of Hydrometeorology and Environmental, "Notification and climate forecasts in January, February, March, 2011," Ha Noi, 2010.

[4]. QCXDVN 02: 2008/BXD, "Vietnam construction standards - Data natural conditions for construction (Part I)," ed. Ha Noi, 2008.

[5]. D. G. Fredlund, H. Rahardjo, and M. D. 
Fredlund, Unsaturated Soil Mechanics in Engineering Practice. Canada: John Wiley \& Sons, Inc, 2012.

[6]. G. S. I. Ltd, Seepage Modeling with SEEP/W 2007, An Engineering Methodology, Third Edition, User's guide. Calgary, Alberta, Canada, 2008.
[7]. G. S. I. Ltd, "Stability Modeling with SLOPE/W 2007, An Engineering Methodology, Third Edition, User's guide," ed. Calgary, Alta., Canada, 2008. 